Ceux-ci ne devraient pas réagir à de telles situations par la censure, mais plutôt fonder leurs décisions sur des considérations plus globales témoignant d'une vision à long terme, les amenant ainsi à générer d'authentiques débats intellectuels, professionnels et sociaux autour de questions et d'enjeux importants pour la santé.

\section{Richard Massé}

Président directeur général

Institut national de santé publique du Québec

\section{Richard Lessard}

Directeur général

Département de santé communautaire de Montréal

Montréal, Que.

$\mathrm{Au}$ nom des membres suivants de la communauté scientifique et de santé publique du Québec, rattachés aux universités de Montréal, McGill, Laval et Sherbrooke ainsi qu'aux départements des centres hospitaliers universitaires de Montréal, McGill et Québec (dans l'ordre alphabétique) : Alix Adrien, Ginette Beaulne, Michèle Beaupré Bériau, Pierre Bergeron, Luc Boileau, Anne-Marie Bourgault, John Carsley, Christine Colin, Richard Côté, Suzanne DeBlois, Philippe DeWals, Bernard Duval, Patricia Goggin, Maryse Guay, Nicole HébertCroteau, Pierre Joubert, Mylène Kosseim, MarieClaire Laurendeau, Dominique Lesage, Patrick Levallois, Réal Morin, Josée Morisset, Gilles Paradis, Robert Perreault, Raynald Pineault, Léo-Roch Poirier, Yvonne Robitaille, Denis A. Roy, Jocelyne Sauvé, Julio Soto, Marc Steben, Jean-Philippe Weber.

DOI:I0.1503/cmaj.I060I26

\section{Accountability in CMAJ}

One of the questions arising from the recent firing of $C M A$ 's editor and senior deputy editor is "To whom should the Journal and its editorial board be accountable?"1

If the $C M A J$ is directly accountable to its publisher, CMA Media Inc., then it effectively does not have editorial independence, despite claims to the contrary. However, I believe that CMAJ should not be directly accountable to any one organization, even its owner. The CMAJ is accountable to CMA Media to prepare a journal for publication every 2 weeks - that is all. In fact, it is CMA Media and the Canadian Medical Association that are responsible to Canadian physicians, the Canadian public, the world medical community and medical scholarship in general to ensure that we have an independent medical journal.

The $C M A J$ should first and foremost be accountable to its principles, and these principles must be clearly stated. In addition to articles on research and clinical medicine, the journal should be committed to publishing news and commentary about trends in Canadian and world medical practices and policies, as well as environmental issues and international health. The intersection of arts, medicine and life is also a relevant topic.

CMAJ should also be accountable to its readers, especially CMA members (after all, it is "our" journal), to the Canadian public, and to the community of world medical scholarship and publications.

\section{Tushar Mehta}

Emergency Physician

Georgetown Memorial Hospital

Georgetown, Ont.

\section{REFERENCE}

I. MacDonald N, Squires B, Downie J, et al. Reflecting on governance for $C M A J$ [editorial]. CMAJ 2006;I74(II):I537.

DOI:Io.I503/cmaj.Io6or2I

\section{Chronic fatigue}

Jacques Cornuz and colleagues, ${ }^{1}$ in Box 2 of their case report, list II initial laboratory tests for patients with prolonged or chronic fatigue. Given that hypocortisolism is one of the most frequently reported abnormalities of patients with chronic fatigue syndrome, ${ }^{2-5}$ it is surprising that none of the available tests for assessing cortisol production ${ }^{2-5}$ was included. The importance of this assessment is especially evident in light of the virtually complete recovery of patients with chronic fatigue who are treated with low-dose hydrocortisone. ${ }^{6}$

Another rationale for assessing cortisol production in patients with chronic fatigue is the fact that this condition shares 43 clinical features with Addison's disease, ${ }^{7,8}$ including hypocortisolism, chronic fatigue, and all of the symptoms listed in the diagnostic criteria for chronic fatigue. ${ }^{7}$ This impressive clinical overlap between 2 distinctly named diseases suggests that in practical terms, chronic fatigue should be regarded as a mild form of Addison's disease. ${ }^{7}$

Although Cornuz and colleagues, in Table I of their paper, correctly mention Addison's disease as one of the major underlying causes of fatigue, they should have remarked that "pigmentation in skin creases, scars and buccal mucosa" ${ }^{1}$ is far from being a constant feature of Addison's disease. ${ }^{9,10}$ Therefore, the absence of such pigmentation in patients with chronic fatigue should not mislead general practitioners to exclude hypocortisolism as a possible cause of that unremitting symptom.

\section{Riccardo Baschetti}

Medical Inspector of the Italian State

Railways (retired)

Fortaleza (CE), Brazil

\section{REFERENCES}

I. Cornuz J, Guessous I, Favrat B. Fatigue: a practical approach to diagnosis in primary care. $C M A J$ 2006; I74(6):765-7.

2. Jerjes WK, Peters TJ, Taylor NF, et al. Diurnal excretion of urinary cortisol, cortisone, and cortisol metabolites in chronic fatigue syndrome. J Psychosom Res 2006;60:145-53.

3. Roberts AD, Wessely S, Chalder T, et al. Salivary cortisol response to awakening in chronic fatigue syndrome. BrJ Psychiatry 2004;I84:I36-4I.

4. Cleare AJ, Blair D, Chambers S, et al. Urinary free cortisol in chronic fatigue syndrome. Am J Psychiatry 200I; $158: 64 \mathrm{I}-3$.

5. Scott LV, Medbak S, Dinan TG. Blunted adrenocorticotropin and cortisol responses to corticotropinreleasing hormone stimulation in chronic fatigue syndrome. Acta Psychiatr Scand 1998;97:450-7.

6. Cleare AJ, Heap E, Malhi GS, et al. Low-dose hydrocortisone in chronic fatigue syndrome: a randomised crossover trial. Lancet I999;353:455-8.

7. Baschetti R. Chronic fatigue syndrome: an endocrine disease off limits for endocrinologists? Eur JClin Invest 2003;33:1029-3I.

8. Baschetti R. Chronic fatigue syndrome, pregnancy, and Addison disease [letter]. Arch Intern Med 2004; I64:2065.

9. Kendereski A, Micic D, Sumarac M, et al. White Addison's disease: What is the possible cause? Endocrinol Invest 1999;22:395-400.

Io. Soule S. Addison's disease in Africa - a teaching hospital experience. Clin Endocrinol 1999;50:115-20.

DOI:I0.I503/cmaj.Io60og8

Recent reports indicate that in addition to viral infections, ${ }^{1}$ chronic bacterial infections may also lead to chronic fatigue syndrome. For example, chronic fatigue syndrome has been di- 
agnosed in patients with Lyme disease, which is caused by intracellular Borrelia infections. ${ }^{2}$ In addition, patients with chronic fatigue may have intracellular Chlamydia spp. or mycoplasmal infections. Brucellosis and tuberculosis are also important causes of chronic fatigue. ${ }^{3}$

Patients with symptoms of fatigue should be screened for these bacterial infections.

\section{Prasanta Padhan}

Department of Internal Medicine Jawaharlal Institute of Post-Graduate Medical Education and Research (JIPMER)

Pondicherry, India

\section{REFERENCES}

I. Cornuz J, Guessous I, Favrat B. Fatigue: a practical approach to diagnosis in primary care. CMAJ 2006 I74(6):765-7.

2. Treib J, Grauer MT, Haass A, et al. Chronic fatigue syndrome in patients with Lyme borreliosis. Eur Neurol 2000;43(2):107-9.

3. Sabin TD. An approach to chronic fatigue syndrome in adults. Neurologist 2003;9(I):28-34.

DOI:I0.1503/cmaj.I060097

Thanks to Jacques Cornuz and colleagues ${ }^{1}$ for reporting the case of fatigue in primary care. Studies here in Australia have highlighted the need for a thorough history and targeted laboratory testing, although most test results will be "normal."

I am interested in what happened next in this case. The woman had laboratory features for celiac disease, but was this the cause of her symptoms? After the biopsy, did she start a gluten-free diet and then undergo another biopsy? Did she feel better on a gluten-free diet? If not, then we still do not have an adequate explanation for her symptoms. We, the physicians, have "treated" ourselves but not the patient.

\section{David Barton}

Medical Adviser

Department of Health and Ageing

Canberra, Australia

\section{REFERENCES}

I. Cornuz J, Guessous I, Favrat B. Fatigue: a practical approach to diagnosis in primary care. $C M A J$ 2006; I74(6):765.
2. Gialamas A, Beilby JJ, Pratt NL, et al. Investigating tiredness in Australian general practice. Do pathology tests help in diagnosis? Aust Fam Physician 2003;32(8):663-5.

DOI:I0.I503/cmaj.1060099

\section{[The authors respond:]}

We agree with Riccardo Baschetti that hypocortisolism is one of the reported laboratory abnormalities of patients with chronic fatigue syndrome and that hypoactivity of the hypothalamicpituitary-adrenal axis is a potential pathophysiologic mechanism. However, as recently stressed by Cho and colleagues, ${ }^{1}$ the question of whether such hypoactivity is a cause or a consequence of chronic fatigue syndrome remains unanswered. Our review ${ }^{2}$ was intended to cover the diagnostic approach to chronic fatigue, rather than treatment, but we can mention here that the results of trials evaluating hydrocortisone therapy have been inconsistent. The first trial assessing this pharmaceutical approach ${ }^{3}$ showed only a modest benefit at the expense of adrenal suppression. To our knowledge, the promising results of a second randomized trial assessing lower dose $\mathrm{e}^{4}$ have never been replicated.

As noted by Prasanta Padhan, the workup for chronic fatigue should be adapted to the local context according to the prevalence of diseases causing fatigue, including bacterial infections. Fatigue has been described in both early and chronic Lyme borreliosis. In one prospective study, fatigue was present in more than half of patients with early Lyme disease, and fatigue was more frequent than arthralgia, myalgia or headache. ${ }^{5}$ In addition, Lyme disease may lead to a post-Lyme borreliosis syndrome including fatigue. ${ }^{6}$ However, the appropriateness of serological testing depends on the probability of disease. Although such testing would be appropriate for a patient with fatigue and a history of erythema migrans (i.e., high pretest probability), it could be inappropriate for a patient suffering fatigue with no objective signs (i.e., low pretest probability) because of the high risk of falsepositive results. ${ }^{7}$ The pretest probability should also be considered for brucellosis and tuberculosis testing. Chlamydia and
Mycoplasma have been found in patients with chronic fatigue and might be associated with the severity of symptoms. ${ }^{8}$

David Barton is correct that most test results for patients with fatigue will be normal, and we agree that physicians must avoid performing diagnostic procedures simply to address their anxiety about a lack of diagnosis. Because our teaching case report represented an amalgamation of cases, there is no follow-up information. However, in a trial involving women with fatigue ${ }^{9}$ (on which one of us [B.F.] was a coauthor) celiac disease was diagnosed by serologic testing and then small-intestine biopsy in 2 patients. One of these patients was lost during follow-up but the other undertook a gluten-free diet and was followed clinically after diagnosis for I2 months. After a few months, she felt better and her fatigue subsided. She underwent a second biopsy I2 months after the diagnosis, which showed no histologic abnormalities.

\section{Jacques Cornuz \\ Bernard Favrat}

Department of Community Medicine and Public Health

University Outpatient Clinic

Idris Guessous

Department of Medicine

University of Lausanne

Lausanne, Switzerland

\section{REFERENCES}

I. Cho HJ, Skowera A, Cleare A, et al. Chronic fatigue syndrome: an update focusing on phenomenology and pathophysiology. Curr Opin Psychiatry 2006; I9(I):67-73.

2. Cornuz J, Guessous I, Favrat B. Fatigue: a practical approach to diagnosis in primary care. CMAJ 2006; I74(6):765-7.

3. McKenzie R, O'Fallon A, Dale J, et al. Low-dose hydrocortisone for treatment of chronic fatigue syndrome: a randomized controlled trial. JAMA I998; 280(I2):I06I-6.

4. Cleary AJ, Hean E, Malhi GS, et al. Low-dose hydrocortisone in chronic fatigue syndrome: a randomized crossover trial. Lancet I999;353:455-8.

5. Nadelman RB, Nowakowski J, Forseter G, et al. The clinical spectrum of early Lyme borreliosis in patients with culture-confirmed erythema migrans. Am JMed 1996;100(5):502-8.

6. Cairns V, Godwin J. Post-Lyme borreliosis syndrome: a meta-analysis of reported symptoms. Int Epidemiol 2005;34(6):1340-5.

7. DePietropaolo DL, Powers JH, Gill JM, et al. Diagnosis of lyme disease. Am Fam Physician 2005;72 (2):297-304.

8. Nicolson GL, Gan R, Haier J. Multiple co-infections (Mycoplasma, Chlamydia, human herpes virus-6) in blood of chronic fatigue syndrome patients: as- 